\title{
CANONS OF LINGUISTIC KNOWLEGDE IN TEXTBOOKS FOR TEACHING TECHNICAL ENGLISH AT AN ACADEMIC LEVEL
}

\author{
MatgorZata HałADEWICZ-GRZELAK, MAGDALENA DolińsKA
}

\section{Introduction ${ }^{1}$}

In Polish universities, teaching vocational English (ESOL) is usually done across two semesters $(2 \times 30$ hours $)$ although it is sometimes limited to only one. Usually, the course is given at the level of MA (MSc) study. It is assumed that students have already acquired General English proficiency at least corresponding to B1 level before enrolling for ESOL. The aim of the present discussion is to analyze and contrast the most frequently practised linguistic and grammatical aspects in the range of coursebooks for teaching Technical English in Polish technological universities and to assess them in respect of the stipulations of CLIL.

Although the syllabus for teaching grammar components in academic teaching in philological departments seems to be well established and methodologically elaborated (e.g. Chrzanowska-Kluczewska; Mańczak-Wohlfred 2008), linguistic descriptions of the grammar canons required in technological academic teaching seem to be missing. A notable exception, although referring to an

\footnotetext{
${ }^{1}$ Portions of this paper were presented at the International Conference GloBe 2013 (20-22 May Warsaw, Poland) and at the LXXI Congress of Polish Linguistic Society [Zjazd Polskiego Towarzystwa Językoznawczego] (23-24 September 2013, Gniezno, Poland). The authors wish to thank the audiences for the discussion and comments.
} 
older generation of coursebooks, is Tay (1976) who, in assessing English in Physical Science (1974) by J.P.B. Allen and H. G. Widdowson, points out that there is "fairly good coverage of the most important grammatical points in seven units. In many exercises, however, the focus appears to be on the subject matter rather than on grammar" (Tay 1976: 84). By way of an illustration, she gives the example of one unit where students spend so much time reading the content and trying to fit the facts together that they lose track of the grammatical point being studied.

Reza-Atai and Shoja (2011) offer crucial insights into the assessment of ESP (English for special purposes) in academic instruction in Iran via a case study of computer engineering students. It can be inferred from their work that the courses in question do not use any particular coursebooks but rely exclusively on reallife materials, without any additional EFL support. The authors conclude that such materials can be problematic for students since many of them do not have an optimal general English proficiency level prior to enrolling on an EAP course. Furthermore, the authors conclude that "[a]s for target needs of the students, it seems that curriculum developers and syllabus designers have neither identified nor defined them operationally in order to formulate specific objectives for the corresponding program" Reza-Atai - Shoja (2011: 38).

General English coursebooks are usually critically assessed for pragmatic or communicative function they are supposed to fulfil. For example, Fish and Dudley-Evans (1986) suggest that in contrast to a grammar-based textbook-oriented syllabus, communication-based ones seem to lack a consensual common core of 'notions' (in Wilkinson's terminology, sematico-grammatical categories). This could stem from the fact that a "syllabus is by definition pre-determined as to the content and sequence whereas communication is in essence open-ended and unpredictable" (Fish and Dudley-Evans 1986: 2). An important study was undertaken by O'Loughin (2012), in which the author studied the vocabulary coverage of the most frequent 2,000 words in a series of New File coursebooks for EFL. The research addressed several important issues, e.g. whether learners are provided with sufficient exposure to vocabulary through reading and listening comprehension components in those materials. ${ }^{2}$

The present case study adopts this latter perspective, being concerned with the status of grammatical and lexis components in technical English coursebooks, rather than with the evaluation of textbooks per se. There is thus the question of how 'grammar' is to be understood in the present paper. According to dictionary definitions, there are at least two meanings of the word 'grammar' (cf. Thornbury 2001: 3). In general, here we take the view that grammar is

\footnotetext{
${ }^{2}$ See also an exhaustive discussion and references on the 'current bilingual situation of the speaker’ (aktualna sytuacja bilingwalna rozmówcy) in Marcinkiewicz (2013).
} 
a body of rules for a language, a system of patterns which describe the formation of a language's sentences. However, as Thornbury (2001: 3) suggests, apart from being a thing, it can also be a process, something that happens, and it can manifest itself in communication. Lexis, in turn, as Jones (1995: 97) observes, is quickly becoming a key concern for SLA studies.The author views the lexicon development in two ways: "as a gradual accretion of individual items or as a series of thresholds linked to the ability to perform a real-life tasts" Jones (1995: 97). Lexicon is understood here, following Kroager, "as a set of meaning elements in a language which we can envisage as a speaker's mental dictionary, where much of information is idiosyncratic and unpredictable but which contains a lot regularities as well" (Kroager 2004: 3). This distinction between the two pivots of building SL skills (lexicon and grammar) will turn out of importance in the discussion to follow.

\subsection{CLIL as a methodology for ESAP}

As Lyster and Ballinger (2011) observe, "CBLT (content based language teaching) is an instructional approach in which non-linguistic curricular content such as geography or science is taught to students through the medium of a language that they are concurrently learning as an additional language" (Lyster and Ballinger (2011: 279). ${ }^{3}$ Currently, the term CLIL (Content and language integrated learning) is preferred, which denotes an innovative attitude to FLT, ensuing from the need to reach higher language skills and to propagate multilingualism in the era of European integration. In L2 teaching, CLIL, apart from the aforementioned CBTL, is also known as English across the curriculum or Bilingual education.

In order to make Europe an economy based on knowledge and competitiveness, the European Commission has created a plan regarding language instruction which aims to achieve an ambitious goal, i.e. MT +2 , that is to say, mother tongue plus two foreign languages. As a result, teaching curricula for foreign languages have become a popular strategy (Swain 1996; Snow and Brinton 1997; Marsh and Hartiala 2001; Wilkinson 2004). Thus far, CLIL has become quite popular in Europe, in particular in secondary education where it successfully supports not only language communication but also intercultural knowledge (Jäppinen, 2005).

As is evident from an evaluation report on bilingual education in Poland regarding the English language (Raport ewaluacyjny - edukacja dwujęzyczna w Polsce - jezzyk angielski), completed in 2008 and coordinated by Centralny

\footnotetext{
${ }^{3}$ The same reference for an overview of CBLT contexts.
} 
Ośrodek Doskonalenia Nauczycieli (CODN) [Centre For Teacher Training] with support from the British Council Poland, CLIL strategies are implemented more and more frequently in secondary education (e.g. bilingual schools in Poland, where selected classes are partly taught in a target foreign language).

So far, CLIL has not been widely adopted in higher education in Poland, although searching through literature on the topic we find suggestions referring to practical implementation of the method and, in that way, elevating English as a medium of instruction. For example, Kruseman (2003) observes that English is the language of science, and it should be pursued if we want to prepare our students for international careers in a globalized word (Kruseman, 2003: 7).

Nevertheless, when teaching English in higher education, this seems to be an ideal ground for implementing CLIL strategies. Among other things:

i) Teaching languages becomes a means for teaching particular problems and students with prior knowledge of a given subject understand better and acquire texts better;

ii) Through interest in the topic, student motivation for learning a foreign language has increased;

iii) Fluency becomes more important than accuracy and errors become a natural part of the learning process;

iv) Language is acquired in natural situations which are known to students, and this creates the ground for the natural growth of language skills;

v) Reading is a necessary skill;

vi) In laboratory groups, determined according to a profile chosen for the main study area, students often have varying degrees of prior FL competence, though they have in common knowledge of the main subject.

Kong and Hoare (2011: 307) point out that teaching content in a second language might be insufficient to bring about language learning (see also Mohan and Huang 2002), hence the exact relation between language and content in content-based language is of paramount importance. What is more, it is teachers' responsibility to integrate the two parts of the dyad, language and content, so as to bring about the learning of both (Kong - Hoare 2008: 254). This work attempts to add to this discussion by investigating the most popular and accessible technical English textbooks from the perspective of integrating grammar content with technical language stipulations. The following research questions were postulated and the subsequent discussion aims to address them:

i) which grammatical canons are omitted in this type of coursebook?

ii) which canons appear the most frequently?

iii) what is the order of explaining grammatical issues and what is the difference (if any) from teaching general English?

iv) what is the importance of procedural teaching and the emphasis on cognitive functions in this type of textbook? 


\subsection{Materials base and the research procedure}

At present the coursebooks on offer for teaching vocational English at an academic level in Poland are quite varied. Apart from the growing market share of books authored by Polish academics teaching vocational and technical English, ${ }^{4}$ practically all established ELT publishing houses currently offer materials for this type of instruction. The actual format of coursebooks differs significantly, even within one publishing house. For example, Engineering workshop is a series of materials, making one volume, of about 32 pages each, and is meant mainly as additional material for classes. On the other hand, for example, Technical English (Technology: Oxford English for carriers. Eric. H. Glendining. OUP ([2007] 2011) is a four-level series, with each level coming with a teacher's book, CDs and a practice book, or the series Career Paths from Express Publishing comes in the format of a topical book (e.g. Sports), with each one containing three smaller textbooks with graded levels of difficulty. ${ }^{5}$

After a preliminary scrutiny of several dozen items, we decided to narrow our investigation to a type of textbook which has a relatively large range in a relatively uniform format. This criterion is satisfied by one-volume books meant as a course for at least one semester of teaching, with additional audio material. Since the range on offer is indeed vast, we further narrowed down the analysis to coursebooks relating to technical English. We assumed that this format and subject might also comprise a grammatical component but, necessarily, since the course consists of only one textbook, such a book could not contain the totality of grammatical topics usually covered on a general English or business English course. Our main research question thus emerged to ask which grammatical topics are most frequently covered in this type of textbook, and with what type of vocabulary are they usually connected. Concomitantly, which aspects of the canonical didactics of grammar are usually omitted in one-volume courses of technical English? The order in which the authors present grammatical content was also tagged as an analytical problem.

The research procedure was as follows. The first stage involved singling out particular textbooks from the pre-established category. From the editorial formats delineated above, we chose, at random, three textbooks for teaching profes-

\footnotetext{
${ }^{4}$ For example, a series of publications by Politechnika Krakowska staff, e.g. English for Environmental Engineering by Małgorzata Grzegozek and Iwona Stalmach.

${ }^{5}$ We can also mention here e.g. i) Energy English for the Gas and Electricity Industries (Paul Dummet, Heinle CENGAGE LEARNING)ii) Engineering - authored by Charles Lloyd, James A Frazier, iii) Technical English Longman, iv) Cambridge professional English, Oxford, v) Nexus Oxford (for teaching construction English language, vi) Oxford English for Electrical and Mechanical Engineering (Eric Glendinning, Normal Glendinning Oxford University Press, 1995), vii) Oxford English for Electronics (Eric Glendeninng, John Mc Ewan, OUP 1993).
} 
sional English. We focused on the most prestigious publishing houses present in the Polish ELT market, Oxford and Cambridge Publishing, and only on items which appeared relatively recently with regard to the time of starting the study (in 2007). Since both authors of this paper have been professionally involved with teaching vocational English at a university of technology, an important criterion we set was to choose from among the items we have actually had didactic experience of. The final choice subsumed these terms:

1) InfoTech: English for Computer Engineering $4^{\text {th }}$ edition (Cambridge, author: Santiago Remacha Esteras).

2) Cambridge Professional English: Engineering, (series editor: Jeremy Day). Author: Mark Ibbotson. 2008.

3) Oxford English for Automobile Industry. Author: Marie Kavanagh. 2007.

The next stage involved a detailed scrutiny of the didactic material contained in the chosen samples, and manual annotation of all the grammatical and vocabulary issues together with their context. The result of this stage of analysis was a corpus of data collected in the form of three tables, one for each textbook analyzed. For space-saving purposes, only excerpts are presented in this paper as an appendix. The first two columns contain the description given by the author of a given textbook, the remaining ones are as a result of our work with the texts. We were thus also interested in 'hidden' linguistic content, i.e. the content not stated explicitly in a coursebook syllabus but which appears as practice exercises when developing a given unit topic. The database thus created was subsequently subjected to categorization and grouping with respect to the grammatical content, and the results compared with the assumptions and canons usually taught at a general level of English. The following sections, due to space limitations, only report selected issues relating to the presence of a grammatical component in the three coursebooks.

\section{Analysis and discussion}

\subsection{InfoTech: English for computer users (fourth edition)}

The topics in the InfoTech textbook (meant as an English coursebook for students of computer engineering) are grouped into eight thematic modules, each comprising 3-5 units. ${ }^{6}$ Table 1 shows a sample of the results from the first stage of analysis. The rubric 'language' contains both language functions (e.g. Language functions in a shop: getting and offering help, comparing, asking the

\footnotetext{
${ }^{6}$ Didactic practice shows that during one weekly session $(2 \times 45$ mins. $)$, usually, the material in two suggested units is covered.
} 
price, choosing the right computer for your needs) and grammatical categories (superlatives, countable and uncountable nouns). It might be inferred that this coursebook does not observe a distinction between language functions and the categories of grammatical description.

2.1.1. Grammatical tenses. The present perfect continuous, which is linguistically presented only toward the end of the coursebook (unit 26, module 8), already appears at the beginning of the coursebook in separate questions (e.g. how long have you been...?). Similarly, the tense present perfect already appears in exercises in the unit: I've done that, anything else? or when practising the superlative form of adjectives (our university has bought..., Discuss what you've arranged to do at the weekend, you've learnt to do in the last year or they have created (revolutionary) camera in unit 6.

Equally surprising is the rift between the grammatical description and the practical use of the past simple tense in the coursebook. The official entree into the syllabus for the tense is only made in unit 19, i.e. towards the end of the book. However, the tense is used practically in the first units in the book, e.g. exercises practising the use of relative pronouns (unit 3) usually rely on carrier phrases in the simple past: Last might I met someone [Who] works for GM as a software engineer; Here is the DVD [...] you lent me. Also, unit 6 contains a set of questions in the past simple: Why did you buy that particular model? When did you buy it? etc. It should be noted that these constructions assume a knowledge of question and negation formation in this tense, as well as knowledge of irregular forms of the simple past.

The desinence $\{$-ed $\}$ as such is only explained in unit 25 . There, the author in fact proposes a more linguistic than didactic classification of the function of the morpheme: "we use the -ed form in the following ways: to make the past simple (affirmative) of regular verbs, to make the past participle of regular verbs (remember that not all verbs in the past simple end in -e), to make the past participle of regular verbs, ${ }^{7}$ to make the adjectival form of some verbs - Java applets let you watch animated characters".

A similar problem can be found in the 'official' didactics of the future simple: an explicit description is provided in unit 29 (Present and future trends in gaming, game genres); however, the tense functions practically in the book starting from unit 5 (do you think it will be possible to...). Linguistically and didactically, the tense is described again in the last unit (30) where the form will is contrasted with going to and will have + past participle forms.

\footnotetext{
${ }^{7}$ We should recall here, once more, that forms of the past participle appear in the coursebook practically from the first unit.
} 
2.1.2. Passive voice is already used practically starting from unit 2 , to describe procedures and classifications, e.g. Sockets into which an external device can be connected; ... is presented; data are processed; $Y$ s are classified into $X$ categories; $X$ can be divided, etc. A unit later the continuous aspect appears: The instruction that is being executed. As far as the frequency of usage of grammatical forms is concerned, the passive seems to be the structure appearing most frequently, being used in the majority of units, e.g. unit 3: The instruction that is being executed; the arithmetic logical unit; clock speed is measured in gigahertz; how memory is measured. Linguistic descriptions, in their turn, are only offered in unit 27 , i.e. at the very end of the coursebook, where it is stated that "we form the passive with the verb to be + the past participle of the main verb. It is often used in technical writing to give an objective tone" (p. 136).

Similar mismatches between the curriculum and the real didactic presence of grammatical components were observed in the case of the gerund, adjectives or the imperative. This cursory discussion of the book content shows that the discrepancy between what is inscribed in the rubric as the grammatical focus of the unit and what a given unit in fact contains is quite severe. The discrepancy is of a random and unpremeditated nature in terms of introducing grammatical structures into a unit which, in fact, do not have much to do with the official canon about which they inform as indicated at the beginning of the book. ${ }^{8}$ We can thus risk drawing a conclusion that the coursebook has mainly been constructed in content-wise fashion - thematically and functionally - and that grammatical descriptions seem to have been 'thrown in' at a later stage, in a quite haphazard manner, as if stretching the didactic reality. It is particularly evident in the purely linguistic descriptions which accompany some topics; they are at a high level of abstraction compared with the general profile of the coursebook and seem to have little connection with the rest of the unit. From experience we must emphasize that these descriptions tend to be quite problematic to computer engineering students since they require a high level of meta-linguistic knowledge, and in didactic practice, teachers tend to omit them altogether. For empirical support let us consider an exemplary linguistic description appearing in unit 20:

We use -ing in three ways: as a gerund acting as object, acting as subject as present participle, compositing is combining in parts, object: I enjoy editing, after a preposition (by making) as a complement of a verb (this course involves painting) list of verbs followed by a gerund (avoid, fancy...). Adjectives come after certain words, (sound, become...) can also complement the object of a sentence (this makes them popular and useful)."

\footnotetext{
${ }^{8}$ Here we concentrate of course only on the main text of the textbook, i.e. explicitly the exercises, and disregard longer reading comprehension texts, as it would be impossible to adapt a long text perfectly to suit the suggested unit.
} 
2.1.3. Word formation and derivation. On the other hand, the aspect of vocabulary acquisition and collocation practice seems to be thoroughly and methodologically enforced throughout the coursebook. Didactic material relating to collocations and word formation appears, for example, in unit 1, unit 6 (as adjectival suffixes $\{$-able, -ible, -ant $\}$, or nominal suffixes $\{$-ure, -logy, -ment $\}$ ), unit 12 word-building e.g. blog-blogger, erase-able, install/ation, solid-state. Unit 15 deals with plural types (e.g. facility -lities, analysis/ analyses, formula/e, criterion/ criteria). Unit 17 contains more collocations, e.g. online friends, upload photos, log into bank account, and repeats the definition of a collocation from unit 1, affixal word formation (e.g. e-zine, e-cash, e-pal, cyberslacker). Unit 18 concentrates on an explanation of acronyms, e.g. asap, btw, LOL, ur (as a linguistic focus of the unit). In unit 24 , the author again proposes derivational word formation, e.g. program, programming, programmer, programmable.

2.1.4. General issues. As can be seen, the supremacy of lexicalization over grammaticalization in this coursebook is impressive. Compared with the accidental and eclectic nature of grammatical explanations, coupled with the unexpectedly sophisticated meta-language used to introduce it, the word-formation aspect is methodologically divided into categories and coordinates with the grammatical content. Another astonishing feature that was revealed at this stage of analysis was the total neglect of the grammatical aspect (continuous and perfective): nowhere are continuous or perfect tenses explained or practised. Although the perfective aspect is cursorily discussed towards the end of the textbook, it is scarcely used anywhere in the textbook. As far as modal verb constructions are concerned, we noticed a lack of constructions conveying incertitude or an irrelalis mode (might, could, etc.), though phrases for practising allowing, forbidding and hypothesis formations appear quite often (shouldn't, needn't).

\subsection{Cambridge English for engineering}

As far as this coursebook is concerned, linguistic descriptions or grammatical explanations are practically non-existent. Nowhere is linguistic vocabulary openly presented or elaborated. Exercises do not contain any descriptions of

\footnotetext{
${ }^{9}$ According to Lyons, utterances where the irrealis mode appears (lexically rendered e.g. by modal verbs) tend to be non-factive, that is, they do not commit the speaker to either the truth nor the falsity of the proposition Lyons (1977: 795). In other words, to irrealize a proposition equals mitigating its illocutionary force. Therefore, rendering the proposition in the exhortative mode augments its illocutionary force. It could also be compared to a blend of the cohortative subjunctive and jussive modes.
} 
what particular grammar point is being practised. Does it mean that grammar is effectively non-existent as an ELF component in this coursebook and that 'anything goes'? Let us take a look at the didactic content, from certain units, as rewritten in Table 2.

First of all, the authors, in contrast to the book previously analyzed, clearly distinguish a rubric skills, where particular language functions are defined (e.g. describing, explaining, categorizing, etc.) from the linguistic component (language). The grammatical description given by the authors is as follows:

Words to describe functions

Adverbs for adding emphasis

Phrases for simplifying and rephrasing

Categories

Phrases for describing requirements,

Shapes and 3D figures

for describing suitability,

Verbs of positioning

Views on technical drawings

Phrases relating to tolerance, lengths,

Verbs and adjectives for describing technical problems

Phrases for certainty/uncertainty

verbs for describing repair and maintenance;

Phrasings for suggesting solutions and alternatives

Idioms for redesigning, verbs with re to describe modification,

Types of protective equipment, phrases for emphasizing importance,

Vocabulary for permitting and regulating verbs,

Common language on safety notices,

Words to describe automated systems

Words to describe fluctuations

Words to described test types

Words and phrases for agreeing /disagreeing

Words for linking causes and effects

Words to describe types of forces; words to describe degrees of difference
Verbs to describe movement

Verbs to describe technical advantages

Common materials

Properties

adverbs of degree

Words to describe machining, phrases

Verbs and nouns to describe joints and fixings,

Prepositions of position,

Phrases relating to scale

Verbs for describing s stages of a design process

Words for describing faults

Adjectives with prefixes for describing technical problems

Phrases for referring to issues, quantity and extent

Idioms to describe feasibility

Types of industrial hazards

Terms to describe regulations,

past participles

language style in written notices

Words to describe measurable parameters

Words and phrases for approximating numbers

Words and phrases for stating assumptions,

phrases for comparing results with expectations

Adjectives for describing suitability and performance

factor criterion, considerations

Words to describe capabilities and limits

Since there are no explicit grammar explanations, there is no question of a possible mismatch between the implicit and explicit usage of particular forms in the coursebook. The analysis below thus concentrates mainly on the presence/absence of particular topics as well as their frequency of occurrence. 
Firstly, just as in the previous coursebook, a noticeable feature is the emphasis on the lexicalization of linguistic information and on word formation (e.g. durable, durability, abrasivel abrasion resistance). Much attention is paid to evaluation phrases (especially good, useless when...), complex adjectives for emphasis and collocations of such, e.g. verb + preposition. There are no separate exercises to cover the comparative or superlative degree of adjectives but there are exercises on modifying vocabulary and qualifying adjectives, e.g. a good degree of, insufficiently, relatively, not at all suitable, high quality watches, fairly good. In other words, in similar semantic realms, a strategy to develop lexical access is preferred (lexical concatenation) rather that inoculation of the rules (grammatical concatenation).

2.2.1. Grammatical tenses. Just as in the item previously analyzed, the simple tense is used the most often: the continuous and perfective aspects appear only sporadically in longer audio recordings, as part of a larger dialogue (e.g. We're saying steel is not necessary; have you spoken to the masons about this?); however, there are no separate exercises in the body of the book to practise these. A similar situation obtains with the past perfect, which also appears only sporadically, in dialogues in longer audio recordings. On the one hand, we might suppose that the authors assume that the students have already covered these issues in previous GE instruction. But, in this context, we make a surprising find, by way of example the practice of determiners and recalling the usage of $a$ and an from unit 1 . Clearly then, the reason must be sought somewhere else.

The absence in practice of present/ past/ perfect (continuous) and continuous aspect in the didactics of Technical English is noticeable, given the copious inclusion of the didactics of lexis, in particular, the emphasis on teaching adjectives, nouns and collocations. Similar to the previous item, there are also restrictions on which modal verbs are employed in textbook exercises. As far as future reference is concerned, only will is used, and only in the realm of prediction. $\mathrm{Al}$ other means of referring to future events are missing (e.g. present continuous, going to). Modal verbs appear only in reference to the present or future, and more elaborate construct (e.g. it could have been...) are non-existent. The passive voice, as in the previous study, appears quite frequently in particular units, but only in the present simple and simple past forms: any other tense forms of the passive are absent. ${ }^{10}$

\footnotetext{
${ }^{10}$ We by no means claim that the fact of the popularity of the passive in scientific discourse is our own novel discovery For example, Nelson et al. say that "it is almost axiomatic that the use of the passive is characteristic of 'scientific' writing. Crystal (1997: 385) suggests that the passive is probably the best known grammatical feature of the language of science, while Quirk et al (1985: 166) relate its use to the 'impersonality' and 'objectivity' of that genre. Corpus based studies have generally supported these views (Nelson et all. 2002: 249). On the other hand, the fact, that this
} 
We also note an elaborate use of adverbs, types of action verbs, some of the obvious lexical components of technical vocabulary, and a significant emphasis on vocabulary connected with evaluation, comparing and emphasis. In general, emphasis is placed on the dynamics of learning, which actually seems to parallel the content: content-wise, there are many procedures referring to machine conservation, security procedures and problem-solving procedure, via problem solving checklists.

\subsection{Oxford Business English: English for the automobile industry}

This coursebook introduces some basic vocabulary relating to constructions and the use of vehicles. The book consists of 8 units, each divided into 4 modules. Table 3 shows the results of the first stage of analysis (cf. above).

First of all, as in the Engineering textbook, the syllabus does not contain a rubric for 'grammar'. The authors describe their book in three main rubrics: unit title, topic and useful language skills. Also, in parallel with the first item analyzed, useful language contains both grammatical categories and purely functional ones. And as in the case of Cambridge English for Engineering, nowhere do the authors include, throughout the text, any descriptions or explanations of the grammar structures practised, save for two exceptions: there are just two grammatical points described by the authors, and just as in the case of Engineering, they can be found in the first unit. These categories are adverbs of frequency (unit 1) and the passive (unit 2). Since this coursebook is much shorter than the previous two items, we opt to discuss the content of units, rather than conduct a thematic study.

2.3.1. Units 1-2. As far as these units are concerned, the grammatical content seems to comply with the author's linguistic description. The units operate with only basic vocabulary (descriptions of types of cars); sporadically, a question appears in the present perfect, but only as a fixed expression present perfect (have you thought...). There is also a subjunctive construction if I were you, but only as one of a number of expressions used for recommendation. The main focus in unit 1 is on practice of the present simple tense, as a means to denote a repeated action, and this is accompanied by explanations and enumerations of adverbs of frequency. Unit 2 is devoted to the passive voice, but only in the present simple tense. It can be observed that a didactic note explaining the passive voice is the only grammatical explicit explanation in the coursebook (apart from

elemental finding was clearly confirmed in our database, might point to the fact that other less obvious results might be justified as well. 
a list of adverbs of frequency): "We often use the passive voice to describe a process. It is formed using the verb to be and the past participle (the $3^{\text {rd }}$ form). We use it to say who or what does the action." Among the expressions used for making telephone calls some expressions appear that use the present continuous, and also some fixed expressions (I will call you as soon as I know something). The simple past appears in reading comprehension.

2.3.2. Units 3-4. These two subsequent units do not have an explicit grammar focus; similar to the two previous ones, the grammatical aspect is limited to the present simple, with the exception of some fixed expressions (e.g. in letter writing, I am writing to you) and gerundial expressions in part dedicated to suggesting (why don't we...). Unit 4 is devoted to defining locations in space; however, the 'canonical' form that usually appears here in GE (there is) does not occur, only prepositions are practised (e.g. the brake fluid reservoir is the rectangular container on the right). Just as in the previous unit, the passive is used with word formation having already been introduced, with separate exercises devoted to the problem (e.g. rotation, rotational, to rotate).

2.3.3. Unit 5: present perfect. This unit, meritum-wise, concentrates on performance and technical specifications, and it introduces the present perfect and simple past. It should be observed, however, that the scope with which the tenses appear comes nowhere close to the 'standard' GE teaching dimension. For example, present perfect practice does not contain any adjectives, which are normally given in the didactic use of this tense (e.g. yet, already, ever, just) - it should be recalled that frequency adverbs are listed in detail for the present simple in unit 1. Moreover, no irregular forms appear - in fact practice of this tense is limited to these four sentences and forms: we have enhanced, introduced, reduced and increased. The didactic material is limited to just one exercise, without any explanations (we should recall that such a description was provided for the passive). The unit also contains a section on making comparisons, also without any grammar explanation, though it does include a summary of declension types, but with the exclusion of irregular forms (further, lesser, etc.). The passive form of the present is still used to give dimensions and vehicle specifications ('specs').

2.3.4. The remaining units. None of the remaining units features even a cursory grammar component. Unit 6 , while describing safety in a car-driving context, consolidates modal verbs, which appeared earlier in unit 1 (e.g. you shouldn't). Grammar-wise, it operates within an area similar to the previously described units. We can see single fixed expressions with going to (I am going to 
talk about...) included in a section on multimodal presentations. The next unit also contains some isolated expressions for small talk (e.g. Have you seen..., someone told me the other day that...). There is also a section on word-building (deverbal nouns), e.g. to adapt/ an adaptation. The last unit, dedicated to future trends, contains an aspect of prediction and establishing future trends (e.g. cars will have an autopilot there is no doubt that; I am certain that). The reading comprehension material contains examples of the imperative mode, in which a student is asked to find and reconstruct something.

To summarize, the authors describe their textbook as being at preintermediate to intermediate level. Our analysis of the grammatical contexts points to a much lower level of proficiency: A1/A2 in fact. On the other hand, quite a lot of language functions (e.g. suggesting, recommending) and situations (telephoning) are given space, in terms of particular dialogues, recordings and lists of phrases. Observations from the previous portion of the data seem to be confirmed. There are some grammar explanations, but the authors seem to feel that only the present simple and the passive voice merit explicit linguistic elaboration. At this stage of the analysis, we cannot find a clear explanation for this tendency: if the authors felt that grammar does not have to by introduced and explained explicitly, then why did they make didactic mention of some of the simplest issues, such as indefinite pronouns, the simple past and the passive, while at the same they sporadically introduce other grammatical constructs without the slightest indication to the learner of their grammatical importance. A possible explanation may lie in the fact that the authors perhaps are specialists more in the content part of the curriculum (technical aspect) than in the language part.

\section{Conclusion}

This case study addressed one of the CLIL dilemmas, which can be worded after Lyster and Ballinger (2011) as "how to make subject matter content comprehensible to learners, whose knowledge of the subject matter might be only partial, without simplifying the curricular content to the point of shortchanging the students" (Lyster and Ballinger 2011: 238).This examination was conducted as a case study of the status of grammar in technical English coursebooks and based on a dataset comprising the content of three coursebooks intended to teach technical English at an academic level. We did not aim at an evaluation of the textbooks as such, rather they were treated as a random source of data to offer insights into the nature of scientist discourse. The main questions we have tried to answer relate to the mutual status of grammatical and lexical component sin ESL instruction, as well as compliance with CLIL tendencies. 
All of the items researched imply something of a 'meritoric' content, which to a large extent liaises with the main subject matter that students in Polish universities of technology cover during their regular study courses, and all of them were actually used as coursebooks at Politechnika Opolska (Opole University of Technology). InfoTech was one of the coursebooks used with MSc students of Computer Engineering, while selected units from Cambridge English for Engineering and Oxford English for the Automobile Industry were used with MSc students of Machine Construction Engineering and students enrolled in Automation and Robotics. A large proportion of the topics and vocabulary from the analyzed books correspond in actuality to basics of their study curricula, e.g. assessing manufacturing techniques (students of machine engineering). In this respect, all the items under analysis imply learning 'through' language or, more precisely, mapping their prior subject knowledge onto relevant English correspondents.

Nevertheless, the analysis reveals that there remain realms of CLIL which so far seem to have escaped scholarly attention. Cambridge English for Engineering and Oxford English for the Automobile Industry can be assumed to comply more with CLIL tenets, in that they have a considerable number of language functions and seem to invite the learner to apply particular expressions practically through procedures. On the other hand, InfoTech was evaluated rather negatively as far as CLIL stipulations are concerned, because grammatical explanations comprise a major part of the book and these didactic explanations do not fit the factual grammar content of the book. The grammar component as such is neither systemized nor broken down into gradual steps of increasing complexity. Rather, a learner is 'thrown in at the deep end' into a full range of grammar usage; and subsequent didactic and linguistic descriptions of particular grammatical structures seem to have been added at a later stage. The remaining two books do not pretend to explain grammar (apart from the aforementioned cases of the simplest of explanations, but with no context).

Other findings concerns the actual level of instruction. As mentioned above, in the case of the third coursebook there is a huge gap in what the author claims is the level of the book and the factual content. In the remaining two, the gap might not be that acute, although there seems to be a different problem: the grammatical content, as has been shown (and we rely here not on descriptions but on real occurrences of particular forms in the exercises), generally corresponds to a level of A2 to lower B1. The lexicon, however, disregarding its purely technical content, seems to be much better developed. This is clear in particular in the case of Cambridge English for Engineering, in its reading and listening comprehension texts; although these are not very complex in terms of grammar, they involve lexical variegation, which can tentatively establish a level of B1 to lower B2. 
This is on a par with another observation regarding the type of learner's cognitive engagement profiled in vocational English textbooks. In particular, we mean here the tendency to omit or avoid grammar, i.e. to avoid linguistic procedures (to recall, grammaticalization, in Thorbury's terminology, means the process of mapping grammar onto otherwise indeterminately connected words), and instead to give priority to lexicalization: relegating communication to the level of lexicon. To recall, lexicon is considered to consist of resources for direct and fast access, available, so to speak, 'on the spot' to the user. Grammatical structures, on the other hand, involve the manipulation and mental processing of acquired algorithms.

A final conclusion which we would like to draw as a contradistinction to GE teaching is the visible neglect of the grammatical aspect: i.e. the perfective and the continuous, (e.g. implying past perfect, present perfect and continuous tenses). This omission consistently surfaced in all three analyzed datasets and is all the more astonishing when we take into account that it is precisely this aspect of English grammar that constitutes the lion share's of ELF didactics and is introduced already at the A2 level of instruction. This absence, as we wish to emphasize, does not ensue from the absence of grammatical structures as such because, as we have shown, in spite of being communicatively based, isolated grammatical issues do appear in the textbook. The fact that these forms appear in long audio recordings might suggest that the learner is expected to recognize, which is a passive strategy, rather than produce such forms. Along these lines, 'significant absence' refers also to all forms of stating incertitude (might, second and third conditional, could have been, etc.) in contrast to the frequency of didactics of allowance, forbiddance and advice.

As can be seen, the topic of content-language proportions raised already by King and Hoare (2011), and evident in current approaches within CLIL framework, has a lot of unexplored facets. The present work also opens up the possibility of a more detailed follow-up study. First of all, a more detailed combined vocabulary and grammar search could be merited, and also empirical studies by means of longitudinal investigation of the effects of technical English instruction on particular grammar skills. We hope, nonetheless, by means of the present exploratory investigation, to draw attention to the relatively neglected aspect of teaching adults vocational English and to the factual language content that textbooks on the market have to offer. We also hope to draw attention to the possibility of the future effects this selective approach to the language realm might have on the nature of vocational communication, given that, in reality, the level of English of adults starting this type of course might not have included a through grounding in all grammatical and functional aspects. 


\section{Bibliography}

Chrzanowska-Kluczewska, E. and E. Mańczak-Wohlfeld. 2008. "Teaching English grammar to Polish students at the academic level". Studia Linguistica 125. 29-40.

Coleman, J.A. 2006. "English-medium teaching in European Higher Education”. Language Teaching 39 (1). 1-14.

European Commission. 2005. Communication from the Commission to the Council, the European Parliament, the Economic and Social Committee, and the Committee of the Regions: a new framework strategy for multilingualism. COM (2005) 596 final. Brussels.

Fish, H. and T. Dudley-Evans. 1982. "Problems with communicative syllabuses". RELC Journal 13 (2). $1-9$.

Gozdawska-Gołębiowska, H., Marsh, D. and M. Zając. 2008. Raport ewaluacyjny: edukacja dwujęzyczna $w$ Polsce (jezzyk angielski). Praktyka $w$ wybranych szkołach. Warszawa: Centralny Ośrodek Doskonalenia Nauczycieli.

de Graaff, R., Koopman, G.J., Anikina, Y. and G. Westhoff. 2007. "An observation tool for effective L2 pedagogy in Content and Language Integrated Learning (CLIL)". International Journal of Bilingual Education and Bilingualism 10.603-624.

Hoare, P. and S. Kong. 2008. "Late immersion in Hong Kong: still stressed but making progress?" In: Fortune, T.W. and D.J. Tedick. (eds.). Pathways to multilingualism: evolving perspectives on immersion education. Clevedon: Multilingual Matters. 242-263.

Jäppinen, A.K. 2005. "Thinking and content learning of mathematics and science as cognitional development in Content and Language Integrated Learning (CLIL): teaching through a foreign language in Finland". Language and Education 19 (2). 148-166.

Jones, F. 1995. "Learning an alien lexicon: a teach-yourself case study". Second Language Research 11. 95-111.

Kong, S. and P. Hoare. 2011. "Cognitive content engagement in content-based language teaching". Language Teaching Research 15. 307-324.

Kroeger, P. 2004. Analyzing syntax: a lexical-functional approach. Cambridge: Cambridge University Press.

Kruseman, A.N. 2003. "Preface". In: van Leeuwen, C. and R. Wilkinson (eds.). Multilingual approaches in university education: challenges and practices. Maastricht: Universiteit Maastricht / Uitgeverij Valkhof Pers. 7-10.

Lee, R.N.F. and A.-M. Bathmaker. 2007. "The use of English textbooks for teaching English to 'vocational' students in Singapore secondary schools: a survey of teachers' beliefs". RELC Journal 38 (3). 350-374.

Lyons, J. 1977. Semantics. Cambridge: Cambridge University Press.

Lyster, R. and S. Ballinger. 2011. "Content based language teaching: convergent concerns across divergent contexts. Language Teaching Research 15. 279-288.

Marcinkiewicz, J. 2013. „O kognitywnym rozumieniu inferencji oraz transferu językowego w akwizycji L2”. Scripta Neophilologica Posnaniensia XIII. 67-75.

Marsh, D. and A.-K. Hartiala. 2001. "Dimensions of content and language integrated learning". In Marsh, D., Maljers, A. and A.-K. Hartiala. (eds.). Profiling European CLIL classrooms. Jyväskylä: University of Jyväskylä, Finland; European Platform for Dutch Education, The Netherlands. 15-53.

Mohan, B. and J. Huang. 2002. "Assessing the integration and content in a Mandarin as a foreign language classroom". Linguistics and Education 13. 405-433.

Nelson, G., Wallis, S. and B. Aarts. 2002. Exploring natural language: working with the British component of the international corpus of English. Amsterdam: John Benjamins. 
O'Laughin, R. 2012. "Turning to vocabulary frequency in coursebooks". RELC Journal 43. 255-269.

Reza Atai, M. and L. Shoja. 2011. "A triangulated study of academic language needs of Iranian students of computer engineering: are the courses on track?" RELC Journal 42. 305-323.

Swain, M. 1996. "Integrating language and content in immersion classrooms: research perspectives". Canadian Modern Language Review 42 (4). 529-548.

Snow, M.A. and D.M. Brinton. (eds.). 1997. The content based classroom: perspectives on integrating language and content. White Plains, NY: Longman.

Tay, M. 1976. "Review: English in Physical Science (1974) by JPB Allen and H G Widdowson". RELC Journal 7. 81-85.

Thornbury, S. 2001. Uncovering grammar. London: Macmillan Heinemann English Language Teaching.

Wilkinson, R. (ed.). 2004. Integrating content and language: meeting the challenge of a multilingual higher education. Maastricht: Universitaire Pers Maastricht. 


\section{ANNEX: samples of the results from the analytical corpus}

Table 1. Excerpt from the InfoTech database

\begin{tabular}{|c|c|c|c|c|}
\hline \multirow{3}{*}{$\begin{array}{l}\text { Module } \\
\quad 2\end{array}$} & $\begin{array}{l}\text { 5. describing } \\
\text { functions and } \\
\text { features }\end{array}$ & Instructions and advice & $\begin{array}{l}\text { Input devices: it allows the user to } \\
\text { answer... describing features: it } \\
\text { usually features two buttons, it } \\
\text { operates without cables; describing } \\
\text { the keyboard: it moves the cursor to } \\
\text { the beginning of a new line; a } \\
\text { numeric keypad; the mouse is also } \\
\text { used to....when you want to move } \\
\text { an image, you position.... }\end{array}$ & $\begin{array}{l}\text { Describing functions: For }+ \text { gerund: this } \\
\text { is a device for controlling; it's used to } \\
\text { control; it works by detecting; present } \\
\text { simple; will: do you think it will be } \\
\text { possible to... }\end{array}$ \\
\hline & $\begin{array}{l}\text { 6.Describing a } \\
\text { camera }\end{array}$ & Superlatives, suffixes & Facts versus opinions in ads, & $\begin{array}{l}\text { Procedures: the scanned image is sent to } \\
\text { the computer where you can...rules for } \\
\text { forming superlatives, advanced } \rightarrow \text { the } \\
\text { most advanced; suffixes (adjectival): } \\
\text { able, ible, ant, : word formation, noun } \\
\text { suffixes - ure, -logy,- ment... simple past: } \\
\text { when did you buy it; what improvement } \\
\text { would you make to it? Passive voice. }\end{array}$ \\
\hline & $\begin{array}{l}\text { 7. ergonomics, } \\
\text { discussing which } \\
\text { devices would } \\
\text { you most like to } \\
\text { own; }\end{array}$ & Instructions and advice, & $\begin{array}{l}\text { Describing computer screen, aspect } \\
\text { ratio, parameters, ags discharge } \\
\text { display, TFT, in a plasma screen, } \\
\text { images are created by, make sure } \\
\text { your feet rest firmly, you } \\
\text { should...don't put your monitor in } \\
\text { form of the window, you shouldn't } \\
\text { it's a good idea to...don't stare at } \\
\text { the screen }\end{array}$ & $\begin{array}{l}\text { Procedures; how screen displays work; } \\
\text { passive voice, definitions of basic } \\
\text { features, discuss your choice of a screen, } \\
\text { imperative ( in negative as well, should). }\end{array}$ \\
\hline
\end{tabular}

Table 2. Excerpt from the Cambridge Professional English: Engineering database

\begin{tabular}{|c|c|c|c|c|}
\hline & & & & \multirow[t]{2}{*}{ the depth. } \\
\hline \multirow{5}{*}{5} & $\begin{array}{l}\text { Describing types } \\
\text { of technical } \\
\text { problem }\end{array}$ & $\begin{array}{l}\text { Verbs and adjectives for } \\
\text { describing technical } \\
\text { problems }\end{array}$ & $\begin{array}{l}\text { Causing failure: damage to surface, loads from expanding } \\
\text { gases, to block, jam, crack, blow, clog up, leak out, to blow } u p\end{array}$ & \\
\hline & \multirow[t]{2}{*}{$\begin{array}{l}\text { Assessing and } \\
\text { interpreting faults }\end{array}$} & Words for describing faults & $\begin{array}{l}\text { Problem solving process (: observation, process of } \\
\text { elimination, identify the failure, determine action) when does } \\
\text { the fault occur, what action is required? The problem only } \\
\text { occurs from time to time it's a slight problem. Temperature } \\
\text { gauge always goes into red. What does the warming message } \\
\text { say? }\end{array}$ & $\begin{array}{l}\text { Questions in present simple, frequency } \\
\text { adverbs, evaluation adjective (intensity- } \\
\text { major/minor, urgent) process of elimination }\end{array}$ \\
\hline & & $\begin{array}{l}\text { Phrases for } \\
\text { certainty/uncertainty }\end{array}$ & $\begin{array}{l}\text { Are you sure the pushrod's straight? It looks as if, the pipe } \\
\text { might be blocked up, the brake pads could be wom out, it } \\
\text { can't be..obviously it must be }\end{array}$ & Modals and expressing certainty \\
\hline & $\begin{array}{l}\text { Describing the } \\
\text { causes of faults, } \\
\text { discussing repairs } \\
\text { and maintenance }\end{array}$ & $\begin{array}{l}\text { Adjectives with prefixes } \\
\text { for describing technical } \\
\text { problems, verbs for } \\
\text { describing repair and } \\
\text { maintenance; }\end{array}$ & $\begin{array}{l}\text { incorrect, malfunction, imbalance, undetected, inoperable } \\
\text { The breaking force on both types should be the same, too little } \\
\text { air. I doubt it's a blockage in the exhaust system - this would } \\
\text { cause overheating; definitions: action verbs dismantle, replace, } \\
\text { tighten, drain, disconnect, maintenance checklist; a nut } \\
\text { worked loose, which resulted in..... }\end{array}$ & $\begin{array}{l}\text { Verb prefixation, modals of suggestion, cause } \\
\text { and effect; maintenance checklist, action verbs, } \\
\text { sequence of steps. }\end{array}$ \\
\hline & $\begin{array}{l}\text { Discussing } \\
\text { technical } \\
\text { requirements }\end{array}$ & $\begin{array}{l}\text { Phrases for refering to } \\
\text { issues, quantity and extent }\end{array}$ & $\begin{array}{l}\text { Concemed, regarding, with regard to the capacity, regarding } \\
\text { the heat resistance, what temperature will the paint need to } \\
\text { withstand, to what extent, the degree to which it moves can be } \\
\text { varied }\end{array}$ & $\begin{array}{l}\text { Focus on specific issues, questions in present } \\
\text { simple and with will to which extent - } \\
\text { assessing the gradation }\end{array}$ \\
\hline
\end{tabular}


Table 3. Excerpt from the English for Automobile Industry database

\begin{tabular}{|c|c|c|c|c|}
\hline & & Rejecting suggestions & $\begin{array}{l}\text { I don't think that will work. That's not a good idea } \\
\text { because... I'm not sure about that. }\end{array}$ & $\begin{array}{l}\text { Present } \\
\text { simple, future } \\
\text { simple }\end{array}$ \\
\hline & Writing an email & Email phrases & $\begin{array}{l}\text { Thank you for your email. I'm writing to... I'm very sorry } \\
\text { that... Could you...? I'm sending you... I hope that... Let } \\
\text { me know if... Best regards/wishes. }\end{array}$ & $\begin{array}{l}\text { Present } \\
\text { simple, } \\
\text { present } \\
\text { continuous in } \\
\text { fixed } \\
\text { expressions }\end{array}$ \\
\hline \multirow[t]{4}{*}{4} & Identifying objects & Engine parts & Clutch, crankshaft, engine, steering arm, propeller shaft, etc. & nouns \\
\hline & Word formation & $\begin{array}{l}\text { Description of engine } \\
\text { layout }\end{array}$ & $\begin{array}{l}\text { Explode - explosion-explosive (etc) } \\
\text { Is converted / is compressed / is rotated }\end{array}$ & $\begin{array}{l}\text { Word } \\
\text { formation } \\
\text { (verbs, nouns, } \\
\text { adjectives) } \\
\text { Passive voice }\end{array}$ \\
\hline & describing & $\begin{array}{l}\text { Describing position } \\
\text { describing shape }\end{array}$ & $\begin{array}{l}\ldots \text { is located on the right/left-hand side of... / at the } \\
\text { front/rear of .../ on the opposite side of.../ } \\
\text { above/below/next to/beside/ between } \\
\text { Square, rectangular, circular, triangular, cuboid, cylindrical, } \\
\text { spherical }\end{array}$ & $\begin{array}{l}\text { Passive, } \\
\text { prepositions } \\
\text { of place } \\
\text { adjectives }\end{array}$ \\
\hline & Asking for information & Trade fair phrases & $\begin{array}{l}\text { I'd like more information on.../I'm interested in.../What } \\
\text { about...?/Can I take one of these brochures?/Can you tell } \\
\text { me something about...? }\end{array}$ & $\begin{array}{l}\text { Present } \\
\text { simple, modal } \\
\text { verbs }\end{array}$ \\
\hline
\end{tabular}

